\title{
Hybrid Renal Cortical Imaging with Single Photon Emission Computerized Tomography/Computed Tomography in a Pediatric Patient with Severe Caudal Regression Syndrome
}

\author{
Şiddetli Kaudal Regresyon Sendromu Olan Pediatrik Bir Hastada Tek Foton Emisyonlu \\ Bilgisayarlı Tomografi/Bilgisayarlı Tomografı ile Hibrid Renal Kortikal Görüntüleme \\ Selin Kesim, (1 Halil Turgut Turoğlu, @ Salih Özgüven, @ Tunç Öneş, ๑ Tanju Yusuf Erdil \\ Marmara University Faculty of Medicine, Department of Nuclear Medicine, Istanbul, Turkey
}

\begin{abstract}
Caudal regression syndrome (CRS) or sacral agenesis is a rarely seen malformation with a varying degree of structural abnormalities, including multiorgan system dysfunctions, reported with higher incidence among children of mothers with diabetes, as in this case. Spinal anomalies can range from coccyx hemiagenesis to the total absence of lower lumbar vertebrae and sacrum in most severe cases. Herein, we have presented a 9-year-old patient with CRS who had renal failure. Technetium-99m dimercaptosuccinic acid renal scintigraphy revealed bilaterally non-functioning kidneys with no renal cortical uptake. Renal anomalies in CRS with vertebral, anorectal, cardiac, trachea-esophageal, renal, and limb anomalies association include one-sided renal agenesis, multicystic dysplastic kidneys, and ureter duplications.
\end{abstract}

Keywords: Caudal regression syndrome, sacral agenesis, VACTERL association, Tc-99m DMSA renal scintigraphy, SPECT/CT

\section{Öz}

Kaudal regresyon sendromu (KRS) veya sakral agenezi, çoklu organ sistemlerini etkileyen, yapısal anomaliler ile seyreden ve olgumuzda olduğu gibi diyabetik annelerin çocukları arasında daha yüksek sıklıkta görülen nadir bir malformasyondur. Vertebral anomaliler koksiksin kısmi agenezisinden ağır olgularda sakral ve/veya lomber vertebraların total agenezisine kadar değişebilmektedir. Burada, teknesyum-99m DMSA böbrek sintigrafisinde bilateral kortikal aktivite tutulumu izlenmeyen, non-fonksiyonel böbrekler saptanan KRS tanilı 9 yaşında bir pediatrik vaka sunulmaktadır. Tek taraflı renal agenezi, multisistik displastik böbrekler ve toplayıcı sistem duplikasyonları gibi renal anomaliler KRS ile vertebral, anorektal, kardiyak, trakeoözafagial, renal ve ekstremite anomalileri birlikteliğinde görülebilmektedir.

Anahtar kelimeler: Kaudal regresyon sendromu, sakral agenezi, VACTERL asosiyasyonu, TC-99m DMSA böbrek sintigrafisi, SPECT/BT

Address for Correspondence: Selin Kesim MD, Marmara University Faculty of Medicine, Department of Nuclear Medicine, İstanbul, Turkey Phone: +90 2163968648 E-mail: selinkesim@yandex.com ORCID ID: orcid.org/0000-0002-6164-9781 Received: 04.08.2020 Accepted: 24.11.2020 


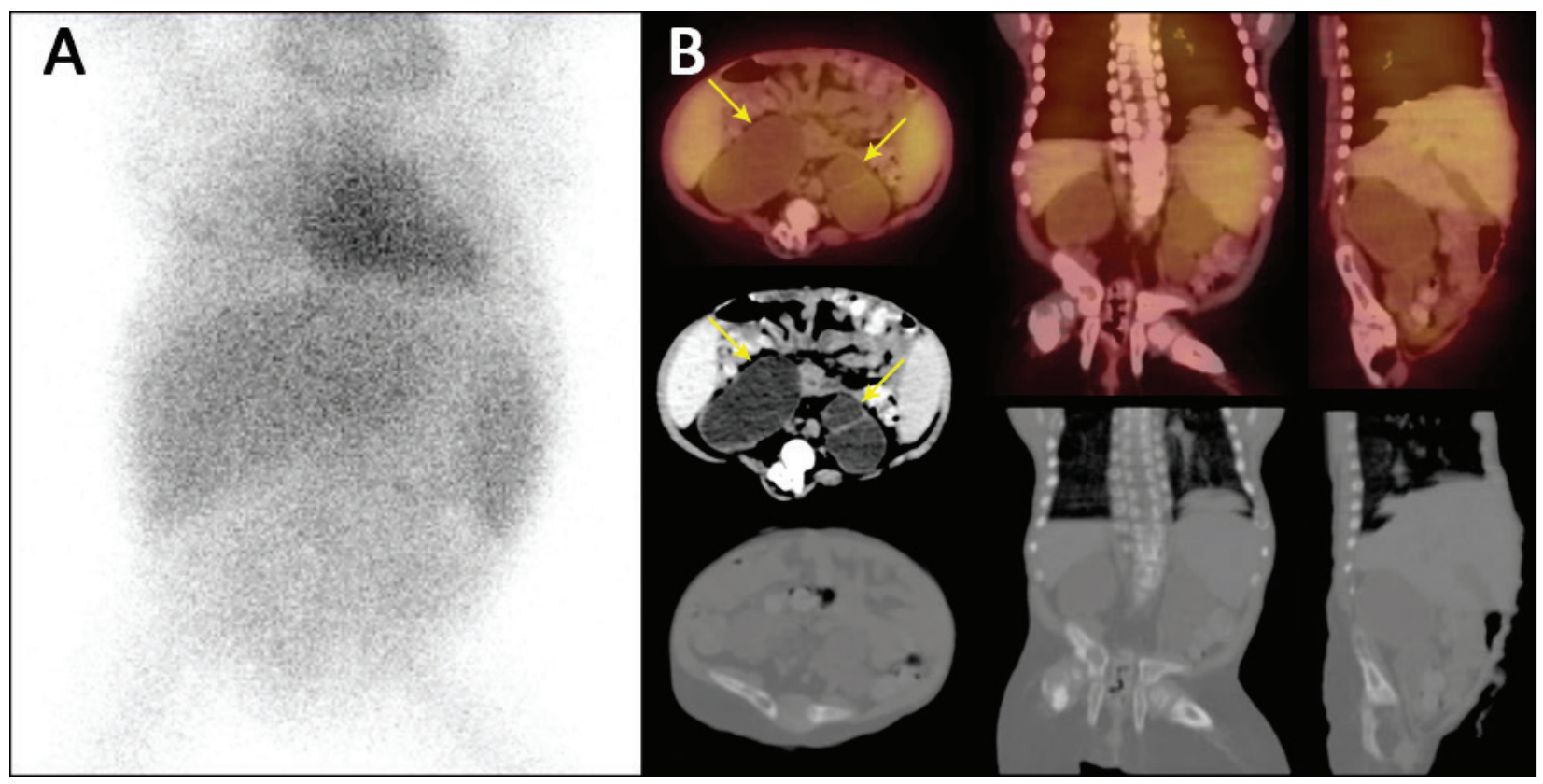

Figure 1. A 9-year-old female patient, who has dysmorphic extremities, growth retardation, congenital scoliosis, rectal, urethral, and sacral agenesis, was diagnosed with caudal regression syndrome (CRS) with a possible etiology of maternal diabetes. Elevated blood urea nitrogen (33 mg/dL) and serum creatinine $(1.85 \mathrm{mg} / \mathrm{dL})$ values necessitated the initiation of dialysis. She was referred to technetium-99m-labeled dimercaptosuccinic acid (Tc-99m DMSA) renal scintigraphy to evaluate renal functions before possible kidney transplantation. Tc-99m DMSA renal parenchymal scintigraphy revealed bilaterally "blood pool" image and increased background activity with no renal cortical uptake of Tc-99m DMSA (A). The hybrid singlephoton emission computerized tomography/computed tomography (SPECT/CT) images demonstrated both kidneys having a cystic pouch appearance (arrows) suggestive of bilateral multicystic dysplastic kidneys (MCDK) with no Tc-99m DMSA uptake in both renal parenchymas consistent with bilaterally non-functioning kidneys, accompanied by bilaterally tortuous and dilated ureters. SPECT/CT also depicted thoracolumbar scoliosis and lumbosacral agenesis involving the bodies and posterior elements of the fourth and fifth lumbar vertebrae (B).

CRS is a rare, neural tube defect that comprises varying degrees of musculoskeletal, gastrointestinal, genitourinary, and cardiovascular system anomalies (1). Its incidence is reported as approximately 0.01-0.05 per 1,000 births, frequent among children of mothers with diabetes (2). Spinal anomalies, which is a characteristic component of CRS, can vary from coccyx hemiagenesis to the total absence of lower lumbar vertebrae and sacrum in severe cases (3). Four types of CRS exist according to the classification of Renshaw (4). Type IV CRS shows variable lumbar and total sacral agenesis, with a caudal endplate of the lowest vertebra resting above the fused iliac bones or iliac amphiarthrosis (4). To fulfill the so-called CRS- vertebral, anorectal, cardiac, trachea-esophageal, renal, and limb anomalies (VACTERL) entity, a minimum of three of six VACTERL anomalies must be present (5). A few cases have been presented on Tc-99m methylene diphosphonate bone scintigraphy in the literature; however, to the best of our knowledge, our case is the first to present Tc-99m DMSA scintigraphy images for CRS-VACTERL $(6,7)$. Urologic anomalies are difficult to identify on clinical examination and form the primary cause of morbidity and mortality. Renal anomalies in CRS-VACTERL association include unilateral renal agenesis, MCDK, and duplication of the collecting system (3). MCDK and hydronephrosis (HN) in newborns both present as fluid-filled masses. Their differential diagnosis is made by the absence (in MCDK) or the presence (in HN) of radiotracer in the fluid. Our case is the late-onset hydronephrotic form of MCDK. TC99m DMSA renal scan is a reliable tool for non-invasive diagnosis of acute and/or chronic kidney injury in children, thus improving the prognosis (8). Hybrid imaging with SPECT/CT technique may help achieve better diagnostic accuracy and impact patient management, as it allows the anatomical correlation of functioning renal parenchymal tissue.

\section{Ethics}

Informed Consent: We have obtained all appropriate patient consent forms. In the form the patient has given her consent for her images and other clinical information to be reported in the journal.

Peer-review: Externally peer-reviewed.

\section{Authorship Contributions}

Surgical and Medical Practices: S.K., H.T.T., S.Ö., T.Ö., T.Y.E., Concept: S.K., H.T.T., Design: S.K., H.T.T., Data Collection or Processing: S.K., H.T.T., Literature Search: S.K., H.T.T, Writing: S.K., H.T.T.

Conflict of Interest: No conflict of interest was declared by the authors.

Financial Disclosure: The authors declared that this study received no financial support.

\section{References}

1. Sharma P, Kumar S, Jaiswal A. Clinico-radiologic Findings in Group II caudal regression syndrome. J Clin Imaging Sci 2013;3:26. 
2. Zaw W, Stone DG. Caudal regression syndrome in twin pregnancy with type II diabetes. J Perinatol 2002;22:171-174.

3. Cunningham BK, Khromykh A, Martinez AF, Carney T, Hadley DW, Solomon BD. Analysis of renal anomalies in VACTERL association. Birth Defects Res A Clin Mol Teratol 2014;100:801-805.

4. Renshaw TS. Sacral Agenesis. The Pediatric Spine -Principles and Practice. Raven Press, New York. 1994;1:2214.

5. Fayyaz $A$, llyas M, lqbal O. Pre-natal diagnosis of caudal regression syndrome. J Coll Physicians Surg Pak 2007;17:425-426.
6. Karacalioglu AO, Soylu K, Emer O, Ayan A, Ozguven M. Incidental finding of sacral hemiagenesis on the (99m)Tc-MDP bone scan as a casual regression syndrome type II. Hell J Nucl Med 2008;11:175-178.

7. Nguyen $\mathrm{BD}$, Civelek $\mathrm{AC}$. Bone scintigraphy of caudal regression syndrome. Clin Nucl Med 1996;21:802-804.

8. Harisankar CN, Mittal BR, Bhattacharya A, Sunil HV, Singh B, Rao KL. Potential diagnostic role of renal scintigraphy in the management of patients with high anorectal malformation. Hell J Nucl Med 2009;12:260265. 